\title{
Experimental Time-Dependent Deflection of High Strength Concrete Panels
}

\author{
Bayan S. Al Numan ${ }^{1, *}$, Faris R. Ahmed ${ }^{2}$, Zahraa N. Rashied ${ }^{3}$ \\ ${ }^{1}$ Civil Engineering Department, Faculty of Engineering, Ishik University, Erbil, Iraq \\ ${ }^{2}$ Civil Engineering Department, Faculty of Engineering, Koya University, Erbil, Iraq \\ ${ }^{3}$ Geotechnical Engineering Department, Faculty of Engineering, Koya University, Erbil, Iraq \\ *Corresponding author: bayan.salim@ishik.edu.iq \\ Received August 02, 2015; Revised August 25, 2015; Accepted September 06, 2015
}

\begin{abstract}
This work presents an experimental study on both short-term and long-term deflections for a period more than seven months of reinforced high and normal strength reinforced concrete two-way flat plate panels. Four reinforced concrete panels with dimensions of $(960 \times 960 \times 50) \mathrm{mm}$ were investigated with simply supported edges. Concrete cube strength is about $75 \mathrm{MPa}$ for HSC panels, and $30 \mathrm{MPa}$ for the control panel. Sustain load kept along the entire test period and at the end, the loads is removed and the recoverable deflection was measured. It's been concluded that the rate of increase in HSC panels' long time deflection is less than that of NSC panels, also the longterm deflection is highly reduced by increasing the compressive strength of concrete and the long term deflection reduced about $20 \%$ when compressive strength increased from 25 to $65 \mathrm{MPa}$.
\end{abstract}

Keywords: concrete panels, high strength, Two-Way Slab, Long and Short-Term Deflection

Cite This Article: Bayan S. Al Numan, Faris R. Ahmed, and Zahraa N. Rashied, "Experimental TimeDependent Deflection of High Strength Concrete Panels." American Journal of Civil Engineering and Architecture, vol. 3, no. 5 (2015): 153-157. doi: 10.12691/ajcea-3-5-1.

\section{Introduction}

Normal strength concrete by the American Concrete Institute (ACI) [1] definition is a concrete that has a cylinder compressive strength not exceeding $42 \mathrm{MPa}$ (6000 psi). All other concretes are considered highstrength concretes (HSC). Concrete with a cylinder compressive strength of $140 \mathrm{MPa}(20,000 \mathrm{psi})$ is used in high-rise structures in the United States and Europe [2]. In certain laboratories, exotic concretes of $315 \mathrm{MPa}(45,000$ psi) have also been produced [3]. Since concrete has to be reinforced for structural use, the level of ductility of the reinforcement becomes the limiting factor, since higher strength concrete tends to exhibit lower ductility.

This work, based on the experimental program conducted, discusses long-term deflection of HSC slabs. Experimental work for long-term deflection of HSC slabs is made.

\section{Long Term Deflection}

For a concrete structure, to be serviceable, cracking must be controlled and deflections must not be excessive. It must also not vibrate excessively. Concrete shrinkage plays a major role in each of these aspects at the service load behaviour of concrete structures.

Serviceability failures of concrete structures involving excessive cracking and/or excessive deflection are relatively common. Numerous cases have been reported, in Australia [4] and elsewhere [5], of structures that complied with code requirements but still deflected or cracked excessively. In a large majority of these failures, shrinkage of concrete is primarily responsible. Clearly, the serviceability provisions embodied in our codes do not adequately model the in-service behaviour of structures and, in particular, fail to account adequately for shrinkage. In the case of HSC, the difficulty increased further.

The quest for serviceable concrete structures must involve the development of more reliable design procedures. It must also involve designers giving more attention to the specification of an appropriate concrete mix, particularly with regard to the creep and shrinkage characteristics of the mix, and sound engineering input is required in the construction procedures. High strength concrete structures require high standard of construction, involving suitably long stripping times, adequate propping, effective curing procedures and rigorous on-site supervision.

\section{Experimental Investigation}

Stoekl [6], reported the results of 15 years of sustained load study. He reported results for concrete with 28 days cylinder strength up to $50 \mathrm{MPa}$. Failures of specimens loaded to $70 \%$ to $75 \%$ of the short-term strength are reported even for $50 \mathrm{MPa}$ concrete. He concluded that the sustained load strength was around $80 \%$ of the ultimate, regardless of the compressive strength and the eccentricity. 
Ashour and Mahmood [7], presented an experimental and theoretical study on the influence of steel fibers and longitudinal tension and compression reinforcements on immediate and long-term deflections of high strength concrete beams of $85 \mathrm{MPa}$ compressive strength. Test results of eighteen beams subjected to sustained load for 180 days show that the deflection behaviour depends on the longitudinal tension and compression reinforcement ratios and fiber content; excessive amount of compression reinforcement and fibers may have an unfavourable effect on the long-term deflections. The beams having the ACI Code's minimum longitudinal tension reinforcement showed much higher time-dependent deflection to immediate deflection ratio, when compared with that of the beams having about $50 \%$ of the balanced tension reinforcement. The results of theoretical analysis of tested beams and those of a parametric study show that the influence of steel fibers in increasing the moment of inertia of cracked transformed sections is most pronounced in beams having small amount of longitudinal tension reinforcement.

Ghali [8] in 1993 presented a proposed code changes for prediction of immediate and long-term deflections of reinforced concrete members. This study showed that the prediction of the immediate and long-term deflections of reinforced concrete members could be inaccurate for two reasons. First, the uncertainty of the material parameters such as modulus of elasticity, creep coefficient, shrinkage. The second is the use of an inadequate method of analysis.

He concluded also that long-term deflection cannot be predicted accurately by the use of the ACI Code multiplier $(\lambda)$ because the equation does not include several parameters that influence the deflection.

Hall and Ghali [9] in 2000 presents the results of an experimental investigation of the long-term deflection behaviour of concrete shallow beams reinforced with glass fibre reinforced polymer (GFRP) bars. The long-term deflections of the GFRP-reinforced beams are compared to deflections of identical beams reinforced with steel bars. All beams were under sustained loading for approximately 8 months.

The variables were the level of sustained loading and the reinforcement materials: steel or GFRP. The experimental immediate and long-term deflections of both the steel and the GFRP-reinforced beams were compared to calculated deflections using the CEB-FIP Model Code 1990, and the ACI 318-95 code using the recommendations of ACI Committee 209; these references are for steel reinforced concrete members.

The test results indicate that under similar loading conditions and the same reinforcement ratio, the GFRP-reinforced beams had long-term deflections, due to creep and shrinkage, 1.7 times greater than those of the steel-reinforced beams. A comparison of the theoretical and experimental immediate and long-term deflections indicates that the CEB-FIP Model Code 1990 gives reasonable predictions for all beams, and that the ACI 318-95 code, using the ACI Committee 209 recommendations, overestimates the deflections due to the combined effects of creep and shrinkage.

Jawad [10] in 2000 presented a theoretical and field investigation of the long-term deflections concrete two-way slab systems. Extensive field measured two-way slab deflections were made in this work. A multi-storey building with 96 panels was investigated. Measurements were taken using standard levelling technique. The collected data were used to furnish three proposals of a long-term multiplier value suitable for Iraqi conditions. In comparison with various multipliers recommended elsewhere, the second proposal is found to be the best acceptable one according to the local field measurements. A proposed model for calculating the long-term deflections of two-way slabs is presented to be suitable for Iraqi conditions.

\section{Materials and Experimental Program}

\subsection{General}

To produce high strength concretes, several parameters have to be optimized in addition to mix design, although the design of the concrete mixture is a major factor in achieving the desired strength. Several methods can be applied to achieve high strength concrete. In general, highstrength concrete contains strong aggregates, a higher Portland cement content, and a low water/cement or water/cementations ratio. The addition of water-reducing admixtures, superplasticizers, polymers, blast furnace slag or silica fume is common today [2].

\subsection{Materials}

\subsubsection{Cement}

Ordinary Portland cements (OPC) was used in the experimental program. It is produced by Al-Sabe'a Lebanon factory. The cement was kept in closed plastic containers throughout the experimental work to keep the cement in a good condition and to minimize the effect of humidity. Its properties are conformed to the Iraqi specifications No.5/1984 [11].

\subsubsection{Fine Aggregate (sand)}

Al-a'sela natural sand with maximum size of $4.75 \mathrm{~mm}$ was used throughout this work. The grading of the sand was conformed to the Iraqi specification No. 45/1984 [12].

\subsubsection{Coarse Aggregate}

Crushed gravel from AL-Nibaey region was used throughout this work. According to the recommendations of ACI 211.4R-93 [13] for mix selection of high performance concrete, the maximum size of $10 \mathrm{~mm}(3 / 8$ in.) for the crushed gravel was selected. The crushed river gravel coarse aggregate were washed, then stored in air to dry the surface, then stored in containers in a saturated surface dry condition before using.

\subsubsection{Superplasticizer}

High range water-reducing admixture called SP-1 was used throughout the experimental work. The superplasticizer was produced by (Al-AZRAK Company, Jordan) and it is complied with ASTM C494 type A\&F as described in the manual of the product.

\subsubsection{Mixing Water}

Tap water was used for casting and curing all the specimens. 


\subsubsection{Steel Reinforcing Mesh}

One size of normal strength steel wires was used. Wires of size $(\phi 2.5 \mathrm{~mm})$ used as a bottom mesh reinforcement with $5 \mathrm{~mm}$ concrete cover. Yield strength of the wires was determined by tensile test. Results of test showed that the yield strength of the wires of $(\phi 2.5 \mathrm{~mm})$ equal to $420 \mathrm{MPa}$. The number of wires was (21) in each direction at the bottom face.

\section{Experimental Program}

\subsection{Mix Design}

According to the recommendations of the ACI 211.4R 93 [13] several trial mixes were made. Reference concrete mixture was designed to give a 28-day characteristic compressive strength of $65 \mathrm{MPa}$. The cement content was $550 \mathrm{~kg} / \mathrm{m}^{3}$ (and $350 \mathrm{~kg} / \mathrm{m}^{3}$ for normal concrete), water/cement ratio was 0.32 , (1.4\%) superplasticizer by weight of cement, and proportions of mix was found to be [1:1.21:1.8] by weight. Table 1 shows the details of the different types of the concrete mix used in this work.

Table 1. Details of the concrete mixes used in slabs used for Long Term Deflection

\begin{tabular}{|c|c|c|c|c|c|c|c|c|}
\hline \multirow[b]{2}{*}{ Index } & \multirow[b]{2}{*}{ Slab ID } & \multirow{2}{*}{$\begin{array}{l}\text { Cement } \\
\mathrm{Kg} / \mathrm{m}^{3}\end{array}$} & \multicolumn{2}{|c|}{ Aggregate content } & \multirow{2}{*}{$\begin{array}{l}\text { Water content } \\
\mathrm{kg} / \mathrm{m}^{3}\end{array}$} & \multirow{2}{*}{$\begin{array}{l}\text { S.P\% by wt. of } \\
\text { Cement }\end{array}$} & \multirow{2}{*}{$\begin{array}{l}\text { W/C } \\
\text { Ratio }\end{array}$} & \multirow{2}{*}{$\begin{array}{c}\text { Vebe time } \\
\text { sec. }\end{array}$} \\
\hline & & & $\begin{array}{r}\text { Sand } \\
\mathrm{kg} / \mathrm{m}^{3}\end{array}$ & $\begin{array}{l}\text { Gravel } \\
\mathrm{kg} / \mathrm{m}^{3}\end{array}$ & & & & \\
\hline \multirow{3}{*}{$\begin{array}{l}\text { High } \\
\text { strength }\end{array}$} & L1 & 550 & 665 & 990 & 170 & 1.4 & 0.32 & 8 \\
\hline & $\mathrm{L} 2$ & 550 & 665 & 990 & 169 & 1.4 & 0.32 & 14 \\
\hline & L3 & 550 & 665 & 990 & 178 & 1.45 & 0.336 & 13 \\
\hline $\begin{array}{l}\text { Normal } \\
\text { Strength }\end{array}$ & $\mathrm{L} 4$ & 350 & 525 & 1050 & 175 & -- & 0.5 & 6 \\
\hline
\end{tabular}

\subsection{Mixing, Casting and Curing Procedure}

Four slabs of $(960 \times 960 \times 50) \mathrm{mm}$ were cast corresponding to the different types of concrete mixes. These slabs marked (L1, L2, L3 and L4) as shown with the details in Table 1 above. For each slab, three $(100 \mathrm{~mm}$ cube) of concrete were cast. The same mix procedure used in the first part of experimental work was adopted in this part of experimental work. Each slab reinforced with one bottom steel mesh of (21ф2.5 Each Way). Figure 1 shows details of the slabs.

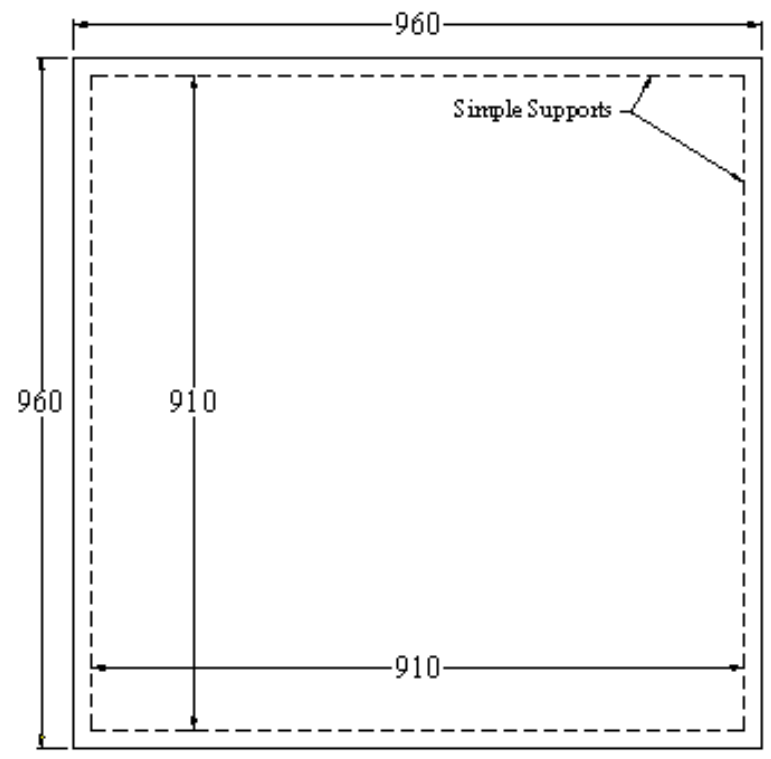

(a) Plan

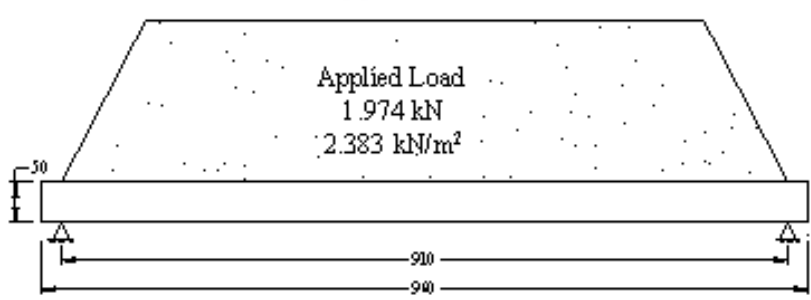

(b) Elevation

Figure 1. Details of slabs for long time deflection test, all dimensions in (mm)

\subsection{Testing Specimens}

All slabs were tested at 28 days age. Before the day of testing, the slabs were taken out from the container of curing, cleaned and painted. All slabs were tested on simple supports and in pure bending by uniform load (sustained load produced by sub-base layer placed on the panels) as shown in Figure 2.

One dial gauge (with an accuracy of $0.01 \mathrm{~mm}$ ) was placed at the center of the bottom face of each panel for reading the deflection after different periods. Nylon sheets were placed on top of slabs to separate concrete from the sub-base load layer. The load of sub-base layer and slab load are $\left(2.383 \mathrm{kN} / \mathrm{m}^{2}\right)$.

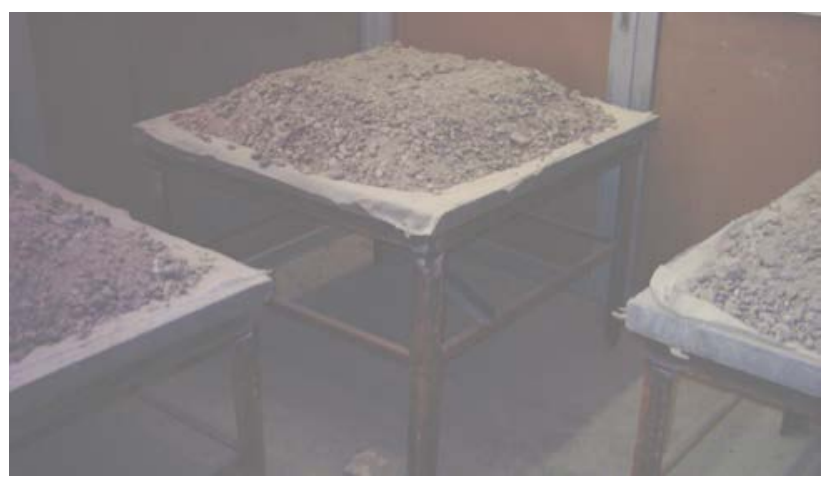

Figure 2. Slabs for long-time deflection test

\section{Panel Specimens Test Results}

\subsection{Short-Term Deflections}

Table 2. Measured Short-Term Deflection

\begin{tabular}{|c|c|c|c|c|}
\hline $\begin{array}{l}\text { Panel } \\
\text { No. }\end{array}$ & $\begin{array}{l}\text { Age of Panel at } \\
\text { Loading (Days) }\end{array}$ & $\begin{array}{l}\left.\mathrm{f}_{\mathrm{cu}}\right) 28 \\
\mathrm{MPa} *\end{array}$ & $\begin{array}{l}\left.\mathrm{fc}^{\prime}\right) 28 \\
\mathrm{MPa} * *\end{array}$ & $\begin{array}{c}\text { Measured } \\
(\Delta \mathrm{s}) \text { mid. } \\
(\mathrm{mm})\end{array}$ \\
\hline L1 & 10 & 74.7 & 63.5 & 0.932 \\
\hline L2 & 10 & 76.2 & 64.77 & 0.904 \\
\hline L3 & 10 & 76.6 & 65.1 & 0.974 \\
\hline L4 & 10 & 29.1 & 24.74 & 1.105 \\
\hline
\end{tabular}

* Cube Compressive Strength.

** Equivalent cylinder comp. strength as per reference 16. 
Deflections are recorded immediately after the panels are loaded in place on their supports. Table 2 summarizes the panels tested, giving actual compressive strength of concrete, age of concrete panel when loaded and measured short-term deflections. The instantaneous deflections are measured for all panels at an age of 28 days [14,15].

\subsection{Long-Term Deflections}

To evaluate the time-dependent deflection behavior, it is necessary to load the panels for a long period of time.
Deflection measurements were taken over a seven-month period under the predetermined level of sustained load permit assessment of this effect.

Plots of the measured midspan deflection versus time for the four panels are shown in Figure 3, It can be seen that the deflection increases with time due to the effects of creep and shrinkage. However, the rate of increase of deflection decreases with time. Also, it is clear that the increase in concrete strength reduces the long-term deflections.

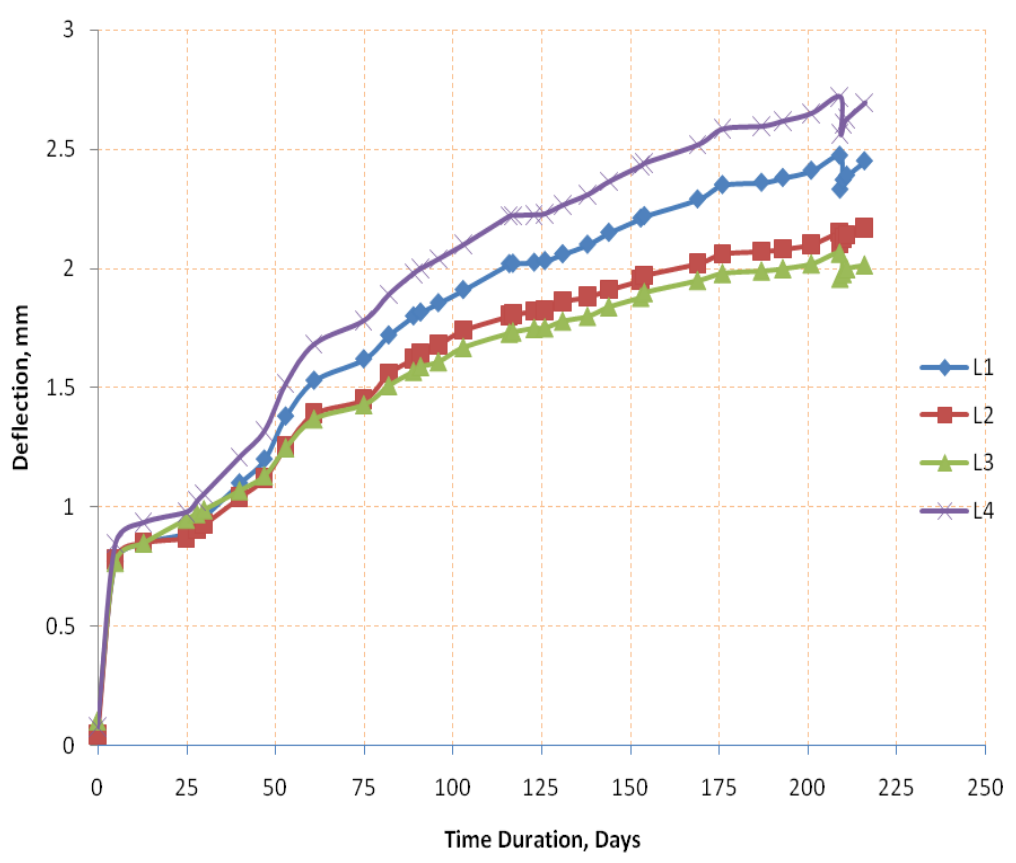

Figure 3. Measured mid-span deflection versus time for the panel L1 to L4

A large increase in deflection is noticed during the first three months after the load is applied. After that, the rate of increase became smaller as time progressed, i.e., in all panels there is a substantial increase of deflection followed by a period where the deflection increases are minimal. Table 3 summarize the measured long-term deflections for each loaded panel. It can be seen that the rate of increase in HSC panels' long time deflection is less than that of NSC panels.

Table 3. Measured Long-Term Deflection for all panels

\begin{tabular}{|c|c|c|c|c|c|c|c|c|}
\hline \multirow[b]{2}{*}{$\mathrm{T}$ in days } & \multicolumn{2}{|c|}{ L1 } & \multicolumn{2}{|c|}{ L2 } & \multicolumn{2}{|c|}{ L3 } & \multicolumn{2}{|c|}{ L4 } \\
\hline & $\begin{array}{c}\text { meas } \\
(\Delta \mathrm{L}) \mathrm{mm}\end{array}$ & $\begin{array}{c}\text { ratio } \\
\Delta \mathrm{L} / \Delta \mathrm{S}\end{array}$ & $\begin{array}{c}\text { meas } \\
(\Delta \mathrm{L}) \mathrm{mm}\end{array}$ & $\begin{array}{c}\text { ratio } \\
\Delta \mathrm{L} / \Delta \mathrm{S} \\
\end{array}$ & meas $(\Delta \mathrm{L}) \mathrm{mm}$ & $\begin{array}{c}\text { ratio } \\
\Delta \mathrm{L} / \Delta \mathrm{S} \\
\end{array}$ & $\begin{array}{c}\text { meas } \\
(\Delta \mathrm{L}) \mathrm{mm}\end{array}$ & $\begin{array}{c}\text { ratio } \\
\Delta \mathrm{L} / \Delta \mathrm{S} \\
\end{array}$ \\
\hline 28 & 0.932 & 1.00 & 0.904 & 1.00 & 0.974 & 1.00 & 1.056 & 1.00 \\
\hline 30 & 0.96 & 1.03 & 0.927 & 1.03 & 0.99 & 1.02 & 1.058 & 1.00 \\
\hline 40 & 1.1 & 1.18 & 1.04 & 1.15 & 1.07 & 1.10 & 1.074 & 1.02 \\
\hline 50 & 1.29 & 1.38 & 1.187 & 1.31 & 1.191 & 1.22 & 1.197 & 1.13 \\
\hline 60 & 1.511 & 1.62 & 1.373 & 1.52 & 1.355 & 1.39 & 1.359 & 1.29 \\
\hline 70 & 1.588 & 1.70 & 1.429 & 1.58 & 1.409 & 1.45 & 1.51 & 1.43 \\
\hline 80 & 1.691 & 1.81 & 1.529 & 1.69 & 1.487 & 1.53 & 1.515 & 1.43 \\
\hline 90 & 1.808 & 1.94 & 1.631 & 1.80 & 1.58 & 1.62 & 1.585 & 1.50 \\
\hline 100 & 1.886 & 2.02 & 1.714 & 1.90 & 1.644 & 1.69 & 1.648 & 1.56 \\
\hline 110 & 1.969 & 2.11 & 1.772 & 1.96 & 1.73 & 1.78 & 1.738 & 1.65 \\
\hline 120 & 2.023 & 2.17 & 1.813 & 2.01 & 1.743 & 1.79 & 1.777 & 1.68 \\
\hline 130 & 2.054 & 2.20 & 1.852 & 2.05 & 1.774 & 1.82 & 1.879 & 1.78 \\
\hline 140 & 2.117 & 2.27 & 1.89 & 2.09 & 1.813 & 1.86 & 1.957 & 1.85 \\
\hline 150 & 2.19 & 2.35 & 1.937 & 2.14 & 1.867 & 1.92 & 2.107 & 2.00 \\
\hline 160 & 2.248 & 2.41 & 1.99 & 2.20 & 1.922 & 1.97 & 2.287 & 2.17 \\
\hline 170 & 2.299 & 2.47 & 2.026 & 2.24 & 1.954 & 2.01 & 2.314 & 2.19 \\
\hline 180 & 2.354 & 2.53 & 2.064 & 2.28 & 1.984 & 2.04 & 2.451 & 2.32 \\
\hline 190 & 2.37 & 2.54 & 2.075 & 2.30 & 1.995 & 2.05 & 2.574 & 2.44 \\
\hline 200 & 2.406 & 2.58 & 2.098 & 2.32 & 2.018 & 2.07 & 2.652 & 2.51 \\
\hline 210 & 2.48 & 2.66 & 2.15 & 2.38 & 2.07 & 2.13 & 2.725 & 2.58 \\
\hline
\end{tabular}


The ratio of deflection increments between the 28-days and 7-months periods vary from 27 to $34 \%$ for HSC panels in average. The corresponding ratios for NSC panels vary from 16 to $25 \%(10,17,18,19,20)$.

At the end of testing period of seven months, the load is removed and the rate of deflection recovery is monitored. Results at the end of seven months testing are summarized in Table 4 , where $(\Delta s),(\Delta \mathrm{i}),(\Delta \mathrm{r})$, and $(\Delta \mathrm{ir})$ are short term deflection at the center of the panel, experimental deflection increment, recoverable deflection, and irrecoverable deflection, respectively.

Table 4. Test Results of Sustained Loading

\begin{tabular}{ccccc}
\multicolumn{5}{c}{ Table 4. Test Results of Sustained Loading } \\
\hline $\begin{array}{c}\text { Panel } \\
\text { No. }\end{array}$ & $\begin{array}{c}\text { short term } \\
\text { deflection } \\
\Delta \mathrm{s}(\mathrm{mm})\end{array}$ & $\begin{array}{c}\text { Exp Def. } \\
\text { increment } \\
\Delta \mathrm{i}(\mathrm{mm})\end{array}$ & $\begin{array}{c}\text { Recoverable } \\
\text { deflection } \\
\Delta \mathrm{r}(\mathrm{mm})\end{array}$ & $\begin{array}{c}\text { Irrecoverable } \\
\text { deflection } \\
\Delta \text { ir }(\mathrm{mm})\end{array}$ \\
\hline L1 & 0.932 & 1.548 & 0.11 & 2.37 \\
\hline L2 & 0.904 & 1.246 & 0.11 & 2.04 \\
\hline L3 & 0.974 & 1.096 & 0.11 & 1.96 \\
\hline L4 & 1.056 & 1.669 & 0.14 & 2.585 \\
\hline
\end{tabular}

\section{Conclusions}

Time dependent deflection up to 210 days was measured for three HS concrete panels ( 65 MPa) and one control panel with (24 MPa).

The following conclusions can be drawn based on the results of this work;

1. The overall trend of deflection-time curves is similar. The high strength panels showed similar or little less values at $1^{\text {st }}$ week and clearly less values at later days.

2. The 210-days center panel deflection for control panel was $(2.725) \mathrm{mm}$, while it was $(2.48,2.15$, and 2.05) $\mathrm{mm}$ for high strength panels. Ratio of $\Delta_{\mathrm{HS}} /$ $\Delta_{\text {control }}$ are $(0.91, .79$, and 0.75$)$, indicating an overall better performance of HS concrete panels in long term deflection.

3. The 210-days ratio of long term to short term deflection $(\Delta \mathrm{L} / \Delta \mathrm{S})$ for control panel was (2.58), the corresponding ratios for HS panels are (2.66, 2.38, and 2.13) with an average of (2.39). They are less than the control panels, however, the values of ACI ratio (2.0) for beams (used for slabs) seems doesn't apply. A values of 2.5 as suggested by Branson [17] sound suitable for normal and HS concrete slabs.

4. A large increase in deflection is noticed during the first three months after the load is applied. At the last three months, the rate of increase became smaller as time progressed.

5. Deflection recovery, when panels were unloaded, had been detected and found to be about 15\%, 18\%, 20\% and $40 \%$ for panels with cube compressive strength 74.7, 76.2, 76.6 and 29.1 MPa respectively.

\section{Abbreviations}

\author{
HSC : High Strength Concrete \\ NSC : Normal Strength Concrete \\ S.P : Supper Plasticizer \\ Meas : Measured \\ W/C : Water / Cement Ratio \\ $\mathrm{f}_{\mathrm{cu}} \quad$ : Cube Concrete Compressive Strength \\ fc' : Cylinder Concrete Compressive Strength \\ $\Delta \mathrm{S} \quad$ : Short Term Deflection \\ $\Delta \mathrm{L} \quad$ : Long Term Deflection \\ $\Delta \mathrm{i} \quad$ : Exp Def. increment \\ $\Delta \mathrm{r} \quad$ : Recoverable deflection \\ $\Delta$ ir : Irrecoverable deflection
}

\section{References}

[1] ACI Code (318-14), "Building Code Requirements for Reinforced Concrete", American Concrete Institute, Detroit, Mich. 2002.

[2] Edwrd G. Nawy, "High Performance concrete", John Wiley \& Sons, Inc., Second Edition, 2001.

[3] Ali, F.A., Abu-Tair, A., O'Connor, D., Benmarce, A. and Nadjai A., "Useful and Practical Hints on the Process of Producing HighStrength concrete", Practical Periodical on Structural Design and Construction, Nov., 2001.

[4] AS3600-1994, Australian Standard for Concrete Structures, Standards Australia, Sydney, (1994).

[5] R.I. Gilbert, "Shrinkage, Cracking and Deflection; the Serviceability of Concrete Structures", Electronic Journal of Structural Engineering, 2001.

[6] Stokal S., "Strength of Concrete under Uniaxial Sustained Loading", SP-34 Concrete for Nuclear Reactors, Vol.1, 1972, pp. 313-326.

[7] Samir A. Ashour and Khalid Mahmood, "Long-Term Deflection of High-Strength Fiber Reinforced Concrete Beams", Structural Engineering and Mechanics, An International Journal, Vol.8, No.6, 1999, pp.236-246.

[8] Ghali, A., "Deflection of Reinforced Concrete Members: A Critical Review", ACI Structural Journal, Vol.90, No.4, JulyAugust 1993, pp.364-373.

[9] Hall, T., and Ghali, A., "Long - Term Deflection of Concrete Members Reinforced with Glass Fiber Reinforced Polymer Bars”, Canadian Journal of Civil Engineering, 2000, (Internet Paper).

[10] Jawad, F.A.F., "Long-Term Deflection of Two-Way Slab Systems: with Particular Focus on Iraqi Practice”, M.Sc. Thesis, College of Engineering, Al-Mustansiriyah University, Baghdad, Iraq, February 2000, 143p.

[11] Iraqi Specifications No. (5), 1984 for Portland Cement.

[12] Iraqi Specifications No. (45), 1984 for Aggregates of Natural Resources used for Concrete and Construction.

[13] ACI 211.4R-93 "Guide for Selecting Proportions for HighStrength Concrete With Portland Cement and Fly Ash", ACI Manual of Cement Practice, Part 1: Materials and General properties of concrete, PP.(13), Detroit ,Michigan 1994.

[14] Figarovskij, V. V., "Experimental Investigation of Stiffness and Cracking of Reinforced Concrete Flexural Members Subjected to Short-Term and Long-Term Loading”, Ph.D. Thesis (in Russian), Moscow, 1962.

[15] Hend K.S. Al-Kubaisy, "Short and Long-Term Deflections of Reinforced Polymer Modified Concrete Panels", M.Sc. Thesis, College of Engineering, Al-Mustansiriyah University, Baghdad, Iraq, Dec 2004.

[16] Neville, A. M. "Properties of Concrete" Pitman publishing Limited, London's 4th Edition 2000, PP. (674-760).

[17] Branson D.E, "Deformation of Concrete Structures", McGrawHill Book Company, 1977, 546 pp. 